\title{
Procalcitonin in Patients Undergoing Chronic Hemodialysis
}

\author{
Martin Schmidt Christian Burchardi Thomas Sitter Eckhard Held Helmut Schiffl \\ Division of Nephrology, Department of Internal Medicine, Ludwig Maximilians University, Munich, Germany
}

Dear Sir,

Procalcitonin (PCT), the precursor of calcitonin, is a new diagnostic parameter for infections. There is evidence for PCT being a more specific parameter indicating systemic bacterial and fungal infections than the nonspecific acute-phase markers C-reactive protein (CRP) or apoferritin. Experimental data and clinical observations have shown that the main stimuli for PCT release are bacterial endotoxins and proinflammatory cytokines as seen in septicemia and bacteremia $[1,2]$. Both uremia and bioincompatibility of hemodialysis (HD) result in a chronic systemic inflammatory syndrome. Even when ultrapure dialysate is used, there is evidence for endotoxins or endotoxin fragments (lipid A, muramyl peptides, molecular weight $<1 \mathrm{kD})$ crossing both low- and high-flux membranes, leading to the activation of monocytes and subsequent release of several proinflammatory cytokines, such as interleukin 1 and tumor necrosis factor alpha [3, 4]. The aim of our investigation was to characterize PCT serum levels in patients without systemic infections undergoing chronic dialysis therapy.

Thirty-six patients on chronic HD and 10 patients on continuous ambulatory peritoneal dialysis (CAPD) were selected for the study on the basis of absence of any clinical evidence for infections during the last 3 weeks prior to the study and being without active immunologic or acute thromboembolic disorders, malignancies, or major surgical procedures $(28$ men and 18 women with a mean age of $58 \pm 24$ years). All patients had been on dialysis therapy for at

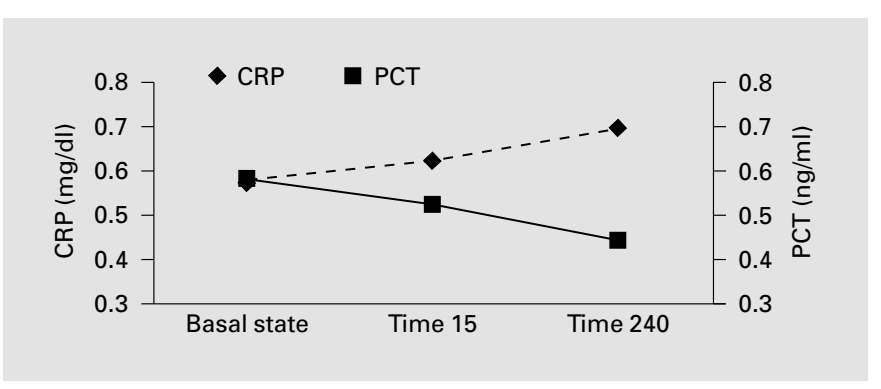

Fig. 1. Mean PCT and CRP levels in 36 patients on chronic HD without systemic infections.

least 3 months. Informed consent was obtained from all patients. Causes of chronic renal failure were chronic glomerulonephritis $(n=14)$, diabetic nephropathy $(n=10)$, interstitial nephritis $(\mathrm{n}=7)$, hypertensive nephropathy $(\mathrm{n}=6)$, nephroangiosclerosis $(\mathrm{n}=1)$, and undetermined causes $(\mathrm{n}=6)$. HD therapy was performed using high-flux membranes (polysulfone F60S, Fresenius, Bad Homburg, Germany; polyarylethersulfone H4, Hospal, Lyon, France) and bicarbonate-based dialysate. In 16 patients ultrapure dialysate was used. The endotoxin count was always below $50 \mathrm{U} / \mathrm{ml}$. Blood samples were taken from the vascular access site prior to dialysis therapy (basal state) and from the efferent line at $15 \mathrm{~min}$ (time 15) and at the end of the HD session (time 240). In the CAPD patients blood was drawn from a peripheral vein at routine visits. The PCT levels were assayed using the LUMLtest ${ }^{\circledR}$, an immunoluminometric assay. The reference range is below $0.5 \mathrm{ng} / \mathrm{ml}$, but in healthy subjects the PCT levels are usually below $0.1 \mathrm{ng} /$ $\mathrm{ml}$ [5]. CRP, leukocytes, and ferritin were sampled at the same time points in EDTA and serum tubes (Sarstedt) and analyzed by autoanalyzer.

PCT was above the detectable level of $0.1 \mathrm{ng} / \mathrm{ml}$ in all 36 chronic HD patients before and at the end of HD. The PCT levels were above $0.5 \mathrm{ng} / \mathrm{ml}$ in 16 patients (44\%) at baseline versus 9 patients $(25 \%)$ at the end of HD. On average the PCT levels decreased from $0.58 \pm 0.35 \mathrm{ng} / \mathrm{ml}$ at baseline to 0.44 $\pm 0.32 \mathrm{ng} / \mathrm{ml}$ at the end of $\mathrm{HD}$ (fig. $1, \mathrm{p}<$ 0.05). In 1 of the 10 CAPD patients, the PCT serum level was $0.8 \mathrm{ng} / \mathrm{ml}$, in the remaining 9 patients the PCT levels were between 0.1 and $0.3(0.23 \pm 0.11) \mathrm{ng} / \mathrm{ml}$. CRP was below

\section{KARGER \\ Fax +4161306 1234 \\ E-Mail karger@karger.ch} www. karger.com (c) 2000 S. Karger AG, Basel

0028-2766/00/0842-0187\$17.50/0

Accessible online at: www.karger.com/journals/nef
Dr. Martin Schmidt

Medizinische Klinik, Klinikum Innenstadt, Ziemssenstrasse

D-80336 München (Germany)

Tel. +49 895160 2220, Fax +49 8951604924

E-Mail Martin.Schmidt@medinn.med.uni-muenchen.de 
the limit of detection $(<0.1 \mathrm{mg} / \mathrm{dl})$ at all time points in 10 patients on HD. CRP levels above the normal range $(0.5 \mathrm{mg} / \mathrm{dl})$ were found in 14 patients $(38 \%)$ at baseline and in 18 patients $(50 \%)$ at time 240 , with a rise from $0.57 \pm 0.44 \mathrm{mg} / \mathrm{dl}$ (baseline) to $0.70 \pm$ $0.51 \mathrm{mg} / \mathrm{dl}$ (time 240). Leukocytes were within normal limits $\left(4-10.8 \times 10^{6} / \mu \mathrm{l}\right)$ in 34 patients $(94 \%)$ at all time points. There was an average decrease in leukocyte count of $11.5 \%$ after 15 min with a slow stabilizing increase towards the end of the HD session, a finding which is in accordance with the well-known phenomenon of transient leukopenia within 15 min after the start of HD. Due to intravenous supplementation of iron aiming at an individual hematocrit level of $33 \%$, the ferritin levels were about twice the normal range.

Our investigation showed that PCT levels are raised above the normal range of $0.5 \mathrm{ng} / \mathrm{ml}$ in almost every second chronic HD patient. According to our results, raised PCT levels confirm the presence of a chronic systemic inflammatory state in HD patients. This is not seen in patients on CAPD. 44\% of all HD patients without clinical or sys- temic signs of infection had raised PCT serum levels in the range of $0.6-1.5 \mathrm{ng} / \mathrm{ml}$, indicating that PCT levels $<1.5 \mathrm{ng} / \mathrm{ml}$ do not allow to differentiate between the inflammatory state in chronic HD patients and incipient systemic bacterial infection. We, therefore, suggest a cutoff level for PCT $<1.5 \mathrm{ng} /$ $\mathrm{ml}$ rather than $<0.5 \mathrm{ng} / \mathrm{ml}$ as normal range in patients undergoing chronic HD. The significant decrease in PCT levels (on average $21 \%$ ) during HD sessions may be explained in part by the use of high-flux membranes. Owing to its molecular weight of $13 \mathrm{kD}$, PCR is abel to pass the membrane. In contrast, CRP is not lost into the dialysate because of its molecular weight of $105.5 \mathrm{kD}$. Dandona et al. [6] have shown that an initial release of PCT in serum can be detected earliest 4-6 h after stimulation of endotoxin. Therefore, it is unlikely to observe a measurable increase of PCT levels during the course of HD. This is the first description of PCT levels during HD in patients without evidence of systemic infections. Further investigations are needed to elucidate the role of PCT in the diagnosis of infections in patients undergoing chronic HD.

\section{References}

1 Assicot M, Gendrel D, Carsin H, Raymond J, Guilbaud J, Bohuon C: High serum procalcitonin concentrations in patients with sepsis and infection. Lancet 1993;341:515-518.

2 Kilger E, Pichler B, Goetz AE, Rank N, Welte M, Mörstedt K, Vetter HO, Gödje O, Schmitz C, Lamm P, Engelschalk E, Muehlbeyer D, Frey L: Procalcitonin as a marker of systemic inflammation after conventional or minimally invasive coronary artery bypass grafting. Thorac Cardiovasc Surg 1998;46:130-133.

3 Hakim RM: Clinical implications of hemodialysis membrane biocompatibility. Kidney Int 1993;44:484-494.

4 Honkanen E, Grönhagen-Riska C, Teppo A-M, Maury CPJ, Meri S: Acute-phase proteins during hemodialysis: Correlations with serum interleukin- $1 \beta$ levels and different dialysis membranes. Nephron 1991;57:283-287.

5 Meisner M: PCT - ein neuer Parameter für schwere Infektionen und Sepsis; in: Biochemische und klinische Aspekte, ed 2. Berlin, Brahms-Diagnostica, 1997, pp 61-77.

6 Dandona P, Nix D, Wilson MF, Aljada A, Love $\mathrm{J}$, Assicot M, Bohuon C: Procalcitonin increase after endotoxin in normal subjects. J Clin Endocrinol Metab 1994;79:1605-1608. 